\title{
Malawi at the crossroads: Does the fear of contracting COVID-19 affect the propensity to vote?
}

Gowokani Chijere Chirwa ( $\square$ gowokani@gmail.com )

University of Malawi, Chancellor College Economics Department https://orcid.org/0000-0003-0199$779 X$

\section{Boniface Dulani}

University of Malawi, Political and Administrative Studies Department

\section{Lonjezo Sithole}

University of Malawi, Chancellor College Economics Department

Joseph J. Chunga

University of Malawi, Center for Social Research https://orcid.org/0000-0002-9216-332X

Witness Alfonso

Institute of Public Opinion and Research, Malawi

John Tengatenga

Institute of Public Opinion and Research, Malawi

\section{Research Article}

Keywords: Corona virus, COVID-19, Voting, Instrument variable, Risk, Malawi

Posted Date: August 5th, 2020

DOI: https://doi.org/10.21203/rs.3.rs-53705/v1

License: (c) (i) This work is licensed under a Creative Commons Attribution 4.0 International License.

Read Full License

Version of Record: A version of this preprint was published at The European Journal of Development Research on January 4th, 2021. See the published version at https://doi.org/10.1057/s41287-020-003531. 


\section{Abstract}

The new coronavirus disease (COVID-19) has disrupted ways of life, including political processes. In this paper, we assess the effect of own perceived risk of catching COVID-19 on willingness to vote. The paper draws from a nationally representative survey of adult Malawians $(n=1155)$. Our main method used instrumental variables to account for potential endogeneity. Findings show that $63 \%$ of Malawians thought that they are likely to catch COVID-19. Notwithstanding the COVID19 risk, 86\% were willing to vote. The regression analysis suggests that an individual's perceived risk of catching COVID-19 is associated with lower likelihood of voting $(\beta=-0.096 ; p<0.05)$. The results suggest that voter turnout in Malawi's fresh presidential election may have been highly affected by the perceived risk of catching COVID-19. The policy implication is that instituting and enforcing primary preventive measures may help reduce the perceived risk of catching COVID19 and mitigate voter apathy.

\section{Introduction And Background}

Credible elections are an important part of putting leaders in power (Lappin, 2009; Abdullah, 2019). Malawi held tripartite elections to choose members of parliament, local government councillors and a president in May 2019. In the presidential race, the candidate for the then ruling Democratic Progressive Party, Peter Mutharika, was declared winner with a plurality of $38.57 \%$ of the vote (Malawi Electoral Commission, 2019). However, the two top losing candidates in the presidential race, Lazarus Chakwera and Saulos Chilima of the Malawi Congress Party and UTM party respectively, went to court to challenge the results, citing mass irregularities in the management of the elections (Tostensen, 2019; Dionne, Kim and Dulani, 2020). Following a seven-month trial, a five-person High Court panel sitting as a Constitutional Court ruled in favour of Chakwera and Chilima and nullified the 2019 presidential election and ordered a fresh poll to be held within 150 days from the date of the ruling on February 3, 2020 (Dionne and Dulani 2020). This ruling was upheld on appeal by the Malawi Supreme Court in a ruling that was delivered on 8 May 2020(Masina, 2020). The Malawi Electoral Commission then set 23 June 2020 as the date for the fresh presidential election.

Whilst Malawi was preparing to hold the fresh presidential election on 23 June 2020, a new pandemic in the name of Coronavirus 19 (COVID-19) (World Health Organization, 2020) hit the country. Even before the country registered its first COVOID-19 case, the government declared a state of national disaster on 20 March 2020. As part of the declaration of a state of national disaster, the Malawi government introduced several measures aimed at curbing the spread of the novel COVID-19, including compulsory screening of all travellers coming into the country upon arrival, a ban on all travellers from highly affected countries, restrictions on public gatherings to a maximum of 100 people and immediate closure of all schools. Additionally, government implored Malawians to practice social-distancing and other preventative measures such as regular handwashing with soap, stopping of handshakes, touching of eyes, nose and mouths and practising cough hygiene by covering mouth and nose with tissue or sleeve or flexed elbow when coughing or sneezing. Individuals who showed symptoms of Covid-19 were also encouraged to seek medical care. 
Notwithstanding these measures, Malawi recorded her first COVID-19 cases on April 2, when three people in the country's capital of Lilongwe were confirmed as Covid-19 positive. As more cases were registered, the government attempted to introduce a national lockdown in the middle

of May. However, this was dismissed as unconstitutional by the courts following a challenge from a leading grouping of civil society organisations. Since then, the number of cases has gradually increased to 3,302 and 76 deaths as of late July 2020 (Public Health Institute of Malawi, 2020).

It is against this background of rising COVID-19 cases that the country went to the polls to choose a new president following the annulment of the 2019 elections. As the number of COVID-19 cases continued to rise, there were calls from various quarters of society asking for a postponement of the elections (Brown and Chinele, 2020; Cooper, 2020; Mohamed, 2020). Among those leading the calls to postpone the elections were public health experts and leading figures from the then ruling Democratic Progressive Party, who called for the need to prioritise the safety of the public over the elections because it would defeat the whole battle against coronavirus.

Due to the highly infectious nature of COVID-19 (Jain and Yuan, 2020; Yang et al., 2020), people may eventually have reservations to queue in lines and vote. The emergence of the disease and the requirement to vote thus put Malawians at the crossroads: whether to risk contracting the virus by coming out to attend campaign meetings and to cast their votes or stay safe and avoid the election process altogether. In view of this, this paper aims to investigate the association between COVID- 19 and the likelihood of voting in an election. Even though the case fatality at the time of the elections was low, there were public health concerns that the community transmissions of COVID-19 in Malawi would exponentially rise due to the large public gatherings during the campaign period and on election day itself. We use data from a household survey comprising 1346 respondents. This study is essential as it links the political economy and public health, as the country navigates towards the realisation of the African Agenda 2063 (African Union, 2020) on achieving functional democracies and the Sustainable Development Goals (SDGs) on developed political institutions, governance and health (UNDP, 2015).

\section{Health pandemics and politics}

Apart from the increased likelihood of the spread of COVID-19 during an election campaign period, the pandemic is having a deleterious impact on economies in short to long term (Ataguba, 2020; $\mathrm{MCCl}$, 2020). Furthermore, the pandemic also has the potential to affect electoral processes (James, 2020; Kavanagh and Singh, 2020), good governance and, more crucially, development outcomes. The implication of the novel COVID-19 is that the impact of the pandemic on economies, politics, governance and the norms that weave the social fabric is still a subject of

exploration and empirical work on these themes remains scant but it is beginning to expand rapidly.

In the months since the advent of the coronavirus pandemic, politics in a number of countries has been affected in unprecedented ways. Countries have had to navigate the balance of the risk of holding an 
election through voting in-person with the potential health hazard of bringing people together in a confined space, against alternative voting methods, and the impact postponing an election would have on upholding of democratic standards (International IDEA, 2020). In West Europe, lockdown measures have been found to raise vote intentions for the party of the incumbent heads of governments, trust in government and satisfaction with democracy (Bol et al., 2020). Across Africa, several countries, including Ethiopia and Uganda, have taken the unprecedented decision to indefinitely postpone elections due to the COVID-19 pandemic (Mohamed, 2020). However, like Malawi, several countries, including Burundi, Guinea, Mali, Tanzania, have decided to go ahead with their elections as scheduled.

However, it is not clear how the elections have affected voter turnout and conduct of elections, for the countries that resolved against postponing them. Landman \& Splendore (2020) argue that the pandemic poses a risk on the election by undermining turnout, among other aspects of the electoral process. However, this has not been tested using public perception data as several countries have taken the decision to postpone elections as a result of the pandemic.

However, previous studies that focus on other health pandemics have established that public health emergencies have a bearing on political behaviour, electoral outcomes, and governance in general (International IDEA, 2020). Civic obligations such as voting, for example, are difficult for people to perform during outbreaks of infectious diseases. Urbatsch (2017) finds that between 1995 and 2015, low voter turnout in elections was associated with regional episodes of influenza outbreaks in Finland and the United States. In two recent polls held during the pandemic in Africa, voter turnout also went down relative to previous elections. Guinea held a plebiscite on constitutional reforms together with legislative elections in March, 2020. The provisional turnout was estimated at 58 percent, much lower compared to the 68.4 percent turnout during the 2015 presidential elections (International IDEA, 2020). In Mali, voter turnout in the first and second rounds of parliamentary elections held in March and April 2020 hovered in the region of 35 percent, compared to roughly 43 percent in the 2013 parliamentary elections (International IDEA, 2020). In the Malawi case, turnout in the June 23, 2020, elections was $65 \%$, which was nine

percentage points lower than the $74 \%$ turnout recorded in the annulled 2019 election. While these anecdotes are by no means evidence of a cause-and-effect relationship between voter turnout and the coronavirus pandemic, the decrease in voter turnout is highly suggestive of a potential link.

A strand of literature much closer to this paper (is from higher-income countries) examines perceptions of risk among different demographics within an electorate and preferences of voters on voting methods. This literature has burgeoned with the advent of coronavirus. A study using county-level state-wide data in Wisconsin at the onset of the coronavirus pandemic found wide disparities in preferences for voting methods such as in-person voting and absentee voting between Democrats and Republicans (Lockhart et al, 2020). The study further established that the choices depended on the perception of risk of coronavirus infection among the voters. There is no study yet examining the $p$ self-perceived perception 
of risk and the propensity to vote during this pandemic in a developing country context where voting is typically in-person. This pioneering study aims to advance the literature in this direction.

It is evident that the COVID-19 is an unprecedented humanitarian crisis requiring urgent and collective efforts to mitigate its impact. The pandemic, among other impacts, impinges on the attainment of development goals, African Agenda 2063 and the SDGs. The virus threatens to reverse years of progress that countries such as Malawi have made towards good health for all in line with the SDG 3. Poor health that may have resulted from the pandemic may further reduce the productivity of labour, thereby affecting one of the essential factors for economic growth (Todaro and Smith, 2012). Since people may not have enough resources, this may exacerbate economic inequality, hence worsening the efforts to tackle the SDG 10 (UNDP, 2018). Thus, this study is important as it stands to contribute to the broader literature by using the quasi- experimental analysis to improve on addressing causality issues regarding COVID-19 and elections outcomes. As such, it provides insights into potential deterrents of SDGs, as well as the African Agenda 2063. Furthermore, to the authors' knowledge, this is the first study to be conducted in a low-income country given that the pandemic is new.

\section{Materials And Methods}

\section{Data}

The research paper used data from the Institute of Public Opinion and Research (IPOR) Pre- election and Governance Survey, which was conducted over a ten-day period between the months of May and June 2020. The IPOR Pre-election and Governance Survey was implemented with financial support from the Open Society Initiative for Southern Africa (OSISA). This was a national study which was conducted in 27 districts across the three regions of Malawi, covering both rural and urban areas. The survey was conducted in a face to face format with randomly selected respondents in the language of their choice: Chichewa, Tumbuka or English, with a multi- stage, stratified random sample drawn from the Malawi 2018 Population and Housing Census sampling frame provided by the National Statistical Office (NSO). Among other things, the survey aimed at contributing to the national discourse on COVID-19 and the fresh presidential elections.

\section{Empirical Strategy}

Both parametric and non-parametric methods were employed in the data analysis. With respect to nonparametric methods, graphs, bar charts, univariate and bivariate analyses were perfomed.

Assuming that the perceived risk of voting and voting are related linearly, the association between perceived risk of catching COVID-19 and voting can be expressed as follows:

\section{$Y_{i}=\alpha_{i}+\theta R I S K_{i}+X^{\prime} \beta+\varepsilon_{i}$}


where $Y_{i}$ is whether the respondent is willing to vote or not; RIS $K_{i}$ is the self-perceived risk of catching COVID -19 by the respondent; $X$ is a vector of controls, and $\varepsilon_{i}$ is the error term of the model. If the error term in equation (1) is not independent from the $R I S K_{i}$ such that $E\left(R I S K_{i} \mid \varepsilon_{i} \neq 0\right)$, then $R I S K_{i}$ is endogenous, suggestive of the presence of confounding factors that have not been controlled for in the equation. This precludes a causal interpretation. Estimating the above relationship using ordinary least squares (OLS) would result in a biased and inconsistent coefficient ( $\theta$ ) (Angrist and Pischke, 2008). To identify a causal effect from observational data, an empirical researcher may choose from an array of causal inference techniques, including matching (Caliendo and Kopeinig, 2008), difference-in-differences (Blundell and MaCurdy, 1999; Bertrand, Duflo and Mullainathan, 2004), synthetic cohort methods (O'Neill et al., 2016) and instrumental variable (IV) methods (Angrist and Pischke, 2008) . In this paper, we apply the IV approach.

With reference to equation (1) above, an IV $(Z)$ is, by way of definition, a variable that is correlated with the perceived risk of catching COVID-19 $\left(R I S K_{i}\right)$, and not the error term $\left(\varepsilon_{i}\right)$. A valid IV must satisfy two conditions, namely: relevance and exogeneity (Angrist and Pischke, 2008). An instrument is relevant if it is highly correlated with the endogenous regressor that is to say [ $\operatorname{Cov}\left(\operatorname{RIS} K_{i}, Z \neq 0\right]$. An IV is exogenous if it is not correlated with the error term such that $\operatorname{Cov}\left(Z, \varepsilon_{i} \mid X_{i} \neq 0\right)$. The intuition behind these two instrument conditions is that the instrument, in effect, splits the variation in the endogenous regressor and captures only the variation in the endogenous regressor that is uncorrelated with the error term, thereby allowing for identification of the causal effect of the explanatory variable on the outcome.

Equation (1) can then be estimated as a two-step procedure: first running equation (2) and then equation (3). Equation three is called the first-stage;

\section{$R I S K_{i}=\delta_{0}+\delta_{i} Z_{i}+X^{\prime} \beta+u_{i}$}

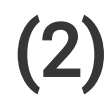

where $R I S K_{i}$ is the perceived risk; $Z_{i}$ is the vector of instruments; $X^{\prime}$ is a vector of controls; $\beta$ is a vector of coefficients; $\delta_{0}$ is a constant; and $u_{i}$ is an error term. To assess whether the instruments were valid, we used the J-Test (Cameron and Trivedi, 2010). We then use predicted values from equation (2) and substitute them for the endogenous regressor in equation (1), to produce equation (3), which is our final estimation as follows;

\section{$Y_{i}=\alpha_{i}+\tau R I S K_{i}+X^{\prime} \beta+\varepsilon_{i}$}

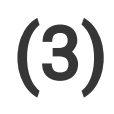

where $\tau$, is our coefficient if interest which measures the effect of perceived risk on voting. RISK is the predicted value of the risk; $X^{\prime}$ are controls with a vector of coefficients $\beta ; \alpha_{i}$ is a constant, and $\varepsilon_{i}$ is an error term, which is now independent of the endogenous variable. 
We instrument our variable of interest using three variables: wearing a face mask, washing hands with soap regularly and perceived risk of a family member catching COVID-19. Based on the recent advice from the WHO and Centre for Disease Control, washing hands with soap and wearing face masks have been recommended as among the most effective ways of preventing catching or spreading COVID-19 (Center for Diseases Control, 2020; Chen et al., 2020; UNICEF, WHO, \& +IFRC, 2020). These attributes are associated with the perceived risk of catching COVID-19. Therefore, we expect that they satisfy the instrument relevance condition. A formal test to check whether this condition in our data was performed. These attributes are, however, independent of the individual's decision to vote. Their effect on voting operates through the individual's perceived risk of catching COVID-19. To that extent, the instrument exogeneity or exclusion restriction condition is satisfied. Since we have multiple instruments, a formal test for whether this condition is satisfied in our data was also performed. All the variables used in the study are defined in Table1. The analysis was done in Stata 16.

\section{Results}

We first present the univariate analysis to show the distribution of our variables in Table 2. As shown in the table, a majority of Malawian adults (86\%) were willing to vote. The perceived risk of catching COVID19 was equally high (63\%). Consistent with the fact that Malawi's population is predominantly youthful, a plurality of the survey respondents were aged between 25 and 34 (28\%). This was followed by the group aged 18-24 (19\%). The lowest percentage were from the age group older than 64 years. In terms of gender, $53 \%$ were males. A majority (55\%) of the respondents had primary education, and almost $82 \%$ agreed with the court's decision to nullify the 2019 presidential election. Regarding self-assessed living conditions, almost $42 \%$ consider their conditions to be very bad, and a lower percentage thought that their living conditions were good. The distribution of social and demographic distributional characteristics can be seen in Table 2.

Moving away from the social and demographic characteristics, we also assessed the differences in the characteristics of the respondents by COVID-19 risk status. Table 3, presents the results for this analysis in four columns, $A, B, C$, and D. Column A, shows the proportion of those who did not consider themselves to be at risk of catching COVID-19. Column $B$ shows respondents who felt they were at risk of catching COVID-19. Column $C$ indicates the difference in the proportions by risk, and column $D$ is the $p$-values of the difference in the proportions. We find that there are a differences among age groups. Regarding sex, many males consider themselves to be more at risk $(d=-0.121 ; p=0.004)$, as do difference by education status, living conditions (Table 3).

\section{Econometric results}

Before presenting the results of the regression, we undertook a battery of tests. When undertaking the IV method, it is to assess whether our variable of interest is indeed endogenous and that the instrument is relevant. On endogeneity, a Durbin-Wu-Hausman tests statistic of $6.47(p<0.011)$ implies that indeed the variable, risk of catching COVID-19 is not exogeneous, hence the need for IV. We also undertook the 
overidentifying restrictions to verify the validity of our excluded instruments. The null hypothesis for the test is that the instruments are not valid. The tests statistic we obtained shows that our instruments were valid (Chi2 $=2.522 ; p=0.283$ ). Lastly, in order to gauge whether our instrument is relevant or not, we also tested the first stage. We use rule of thumb that the $F$-statistic from the first stage should be greater than ten. The resultant $F$-static $(=122.78 ; p<0.000)$ was greater than ten. For more on test for endogeneity, exogeneity, and instrument relevance, see appendices 1, 2 and 3 respectively.

In terms of the results, we first did naïve model of OLS and probit, to see if any significant relationship between the perceived risk of COVID-19 and voting and can be established. The results are presented in columns $(A)$ and $(B)$, respectively. In column $(A)$, whilst the sign is negative, the result is insignificant $(\beta$ $=-0.032$ ). Just as the case was in the OLS, the probit model also does not show any significant relationship between the perceived risk of catching COVID-19 and voting. Moving away from the naïve models, we estimated that IV2SLs and results are shown in column (C).

Looking at the magnitude of the effects, the estimates suggest that the likelihood to vote for those who fear to catch COVID-19 is lower by -0.096 as compared, to those who do not fear catching COVID-19. Despite the significant large magnitude size, it is necessary to bear in mind that the estimates represent a local average treatment effects (LATE). In other words, the estimate is specific to who fear to catch COVID-19. Hence, the coefficients can be interpreted as the causal effect. Despite this, it remains a very large effect.

We undertook some robustness checks to see whether our results are sensitive to different model specifications. We noted, for example, that although members of Jehovah Witness are not allowed by their faith to participate in voting, some members in our sample indicated that they would vote. We thus, run a full model, without the religion variable, and our results are qualitatively similar. See Appendix 4 for details. Besides, we also assessed whether the results are sensitive to the choice of control covariates. We found that the results are stable, as can be verified in Appendix 5 .

Further to this analysis, we also observed that among male rural dwellers, there is a statistically significant negative relationship between the perceived risk of catching COVID-19 and likelihood of voting. In contrast, this relationship was statistically insignificant in the equation for females. Likewise, we also observed a statistically significant negative relationship between the perceived risk of catching COVID-19 and likelihood of voting among rural dwellers but not among urban dwellers (see Appendices 6 and 7, respectively). This suggests some of the voter apathy witnessed in some of the rural parts of the country is potentially attributable to fear of catching COVID-19.

\section{Discussion}

This paper has investigated the relationship between perceived risk of catching COVID-19 and voting in Malawi. We used a household cross-section survey conducted between the months of May and June 2020 when Malawi was preparing for an election against a growing number of COVID-19 cases. Our 
analysis employed, OLS, probit model and IV 2SLS methods. The analysis was robust to various methods. We find interesting results, as follows:

On the univariate analysis, there were two key findings; first, many people were likely to vote in spite of the growing number of COVID-19 cases. Secondly, the proportion of Malawians who thought that they were at risk of catching COVID-19 was high, although previous results suggested that Malawians were more worried about hunger than COVID-19 (GLD-IPOR, 2020). Results from the regression analysis suggest that there is a negative effect of self-assessed risk of catching COVID-19 on the likelihood of voting. The naive models of the OLS and the probit model did not show any significant effect of the perceived risk of catching COVID-19 and likelihood of voting. However, the 2SLS IV method suggest that the risk of catching COVID-19 is associated with a lower likelihood of voting. These effects varied across selfperceived welfare, regions, gender.

Apart from our variable of interest, we also found an interesting relationship between belonging to the Jehovah's witness's faith and voting. It suggests that those who belong to this faith are less likely to vote than others from different religions. Probably, this is in line with their belief on political neutrality (Chand, Subramanya and Rao, 2014). Consistent with other studies of voting behaviour (Bryant and Wahman, 2017; Bleck and Van de Walle, 2018), we found that those living in urban areas are less likely to vote. This may be an indication of relatively higher voter apathy among urbanites (Bryant and Wahman, 2017), which might suggest that the perceived benefits of voting, based on campaign promises, are considered lower among urban folk compared to those residing in rural areas. Although such is the case, among the two mentioned variables, it is quite interesting to observe that those who agree that the court's decision to annul the previous elections was valid, were more likely to vote than those who disagreed. This may be an indication that people felt that indeed the election was invalid and voting would be an issue that would exercise some form of natural justice. This might also explain why the opposition alliance candidate in the elections, Lazarus Chakwera, emerged victorious, as opposition supporters were almost unanimous in agreeing with the annulment of the elections while nearly a third of the then ruling Democratic Progressive Party expressed disagreement with the court decision to annul the 2019 election results.

Also, those who were employed were likely to vote. We may hypothesise that probably, the need for voting was to effect regime change, in order to deal with the economic and political concerns faced by employed Malawians. As such, voting was an important mechanism to channel their anger and express dissatisfaction with the ruling party. In the employment circles, it was observed that most people were bitter with having lower pay and paying high taxes, which may induce the need for regime change. Specifically, many government employees in the country felt that the conditions of services and the current government requires change. Issues such as delayed promotions, non- paid arrears, differed payments, and nepotism, were rampant within the system. However, the government paid a deaf eye to the need to do so. 
Our results on the high levels of fear of the risk of catching COVID-19 can probably help to explain the relatively lower voter turnout in the fresh elections of 23 June 2020 in Malawi. The proportion of the people who came to vote was lower in the June 2020 elections compared to the number who voted in 2019. In 2020 , a total of $4,445,385$ out of $6,859,570$ registered voters turned out to vote, which translates to 64.8 percent. In contrast, 5,105, 983 Malawians voted in 2019, representing 74.4 percent of registered voters The result of voter turn up suffering has also been reported in other countries where elections took place such as Guinea, Cameroun, Mali (Asplund and Akinduro, 2020).

One important thing to note is that despite the COVID-19 affecting the daily lives, life goes on in Malawi with minimal disruption. As pointed out earlier, an attempt by the government to impose a national lockdown was rejected by the courts. This has meant that apart from voting and other electoral processes, most citizens have continued to pursue their livelihoods relatively normally during the pandemic, save for observing social distancing and other limited measures. In view of this, the paper has some important implications for policy. The result that the risk of catching COVID-19 can cause reduced voter turnout, it means that dealing with COVID-19 requires that prevention measures be put in place to reduce the risk of COVID-19 during campaigning and election day itself. For example, since voting involves queuing in lines in Malawi, enforcing social distancing in queues is important in preventing the spread of COVID-19. Furthermore, other preventive measures such as hand sanitising at polling stations and use of face masks by polling staff and voters should be made mandatory (Asplund and Akinduro, 2020). Additionally, polling material must be properly and regularly sanitised in order to reduce the risk of transmission among voters. At the same time, voter education messages should educate the people on proper ways to keep themselves safe during voting. Lastly, election management bodies should explore ways of decongesting polling stations like increasing the number of polling stations so that fewer voters are allocated be station. Where possible, voting options such as online campaigns and postal voting should be explored to reduce cloud congestion as a way of minimising the potential for transmission.

We are cognizant of the limitations that our study has. First, due to data limitations, we were unable to control for the effect of the occupation of the respondent. We would expect the perception of risk to be stronger, for example, among those involved in public health-related occupations on account of their more intimate knowledge of how the disease spreads. Second, the timing of the survey may also affect the nature of our findings. The survey was undertaken in the wake of the annulment of the presidential elections by the courts. We suspect that if this survey had been undertaken prior to the court's decision, the results of our analysis would have possibly been different. We have no tools and data at our disposal to verify this conjecture. It may, therefore, be worthwhile to follow up with the respondents in a future iteration of the survey to check if the respondents who said they would vote indeed went to cast a vote.

\section{Conclusion}

In anticipation of challenges managing elections during the COVID-19 pandemic, several countries have postponed elections to later dates. Only a few countries such as Malawi, Guinea, Mali, Burundi have gone ahead with their scheduled elections while others such as Tanzania and Ghana are pushing ahead with 
plans to hold elections later in the year. While the public health motive to postpone elections is noble, there are concerns that unpopular, and perhaps authoritarian, governments may exploit the pandemic to avoid elections and thereby extend their grip on power. At the same time, illegitimate governments will likely face challenges in mounting an effective campaign against the pandemic. Notwithstanding the political benefits of pushing ahead with elections, the often large gatherings associated with election campaigns and congestion at polling stations increase the risk of exposure to citizens for catching the coronavirus. In developing countries where health services are often of poor quality and already stressed, the effects of a rapid increase in COVID-19 cases due to holding elections can have the effect of creating a major public health crisis even if this addresses any previous political crises. Indeed, evidence from Malawi adduced in this paper has shown that the fear of catching COVID-19 can have the effect of dressing voter turnout in elections, thereby undermining the legitimacy of the government that is elected during times of a health pandemic. While the need for having a legitimately elected government and public safety can be a delicate balance to strike, it is imperative that if elections have to take place during a health crisis such as COVID-19, then all measures be taken to reduce the possibility of transmission to avoid worsening the pandemic in ways that can not only result in increased pressure on public health services but also forestall any future loss of life.

\section{Declarations}

Competing interests: The authors declare no competing interests.

\section{References}

1. Abdullah, W. J. (2019) 'The Mahathir effect in Malaysia's 2018 election: the role of credible personalities in regime transitions', Democratization. Taylor \& Francis, 26(3), pp. 521-536. African Union (2020) Covid -19.

2. Angrist, J. D. and Pischke, J.-S. (2008) Mostly harmless econometrics: An empiricist's companion. Princeton university press.

3. Asplund, E. and Akinduro, O. (2020) How African countries are dealing with elections during COVID19.

4. Ataguba, J. E. (2020) 'COVID-19 Pandemic, a War to be Won: Understanding its Economic Implications for Africa', Applied Health Economics and Health Policy. doi: 10.1007/s40258-02000580-x.

5. Bertrand, M., Duflo, E. and Mullainathan, S. (2004) 'How much should we trust differences-indifferences estimates?', The Quarterly journal of economics. MIT Press, 119(1), pp. 249-275.

6. Bleck, J. and Van de Walle, Nicholas (2018) 'The African Voter', in Bleck, J. and van de Walle, Nicolas (eds) Electoral Politics in Africa since 1990: Continuity in Change. Cambridge: Cambridge University Press, pp. 218-260. doi: DOI: 10.1017/9781316676936.007. 
7. Blundell, R. and MaCurdy, T. (1999) 'Labor supply: A review of alternative approaches', in Handbook of labor economics. Elsevier, pp. 1559-1695.

8. Bol, D. et al. (2020) 'The effect of COVID-19 lockdowns on political support: Some good news for democracy?', European Journal of Political Research. Wiley Online Library.

9. Brown, R. and Chinele, J. (2020) 'Protect the vote, or protect the voter? In African elections, no easy?', The Christian Science Monitor. Available at:

https://www.csmonitor.com/World/Africa/2020/0623/Protect-the-vote-or-the-voter- In-Africanelections-no-easy-choice.

10. Bryant, K. and Wahman, M. (2017) 'Rural voters', in Moghaddam, F. M. (ed.) The SAGE encyclopedia of political behavior. California: SAGE Publications Inc, pp. 725-728. doi: 10.4135/9781483391144.n332 APA.

11. Caliendo, M. and Kopeinig, S. (2008) 'Some practical guidance for the implementation of propensity score matching', Journal of economic surveys. Wiley Online Library, 22(1), pp. 31-72.

12. Cameron, A. C. and Trivedi, P. K. (2010) Microeconometrics using stata. Stata press College Station, TX. Available at: https://www.stata.com/stata-news/statanews.23.4.pdf (Accessed: 28 December 2017).

13. Center for Deases Control (2020) Coronavirus Disease 2019 (COVID-19):How to Protect Yourself \& Others.

14. Chand, N. K., Subramanya, H. B. and Rao, G. V. (2014) 'Management of patients who refuse blood transfusion', Indian journal of anaesthesia. Medknow Publications \& Media Pvt Ltd, 58(5), pp. 658664. doi: 10.4103/0019-5049.144680.

15. Chen, X. et al. (2020) 'Hand Hygiene, Mask-Wearing Behaviors and Its Associated Factors during the COVID-19 Epidemic: A Cross-Sectional Study among Primary School Students in Wuhan, China', International journal of environmental research and public health. Multidisciplinary Digital Publishing Institute, 17(8), p. 2893.

16. Cooper, J. (2020) "To Vote or postpone? Elections in Africa in the time of COVID," Africa Renewal. Available at: https://www.un.org/africarenewal/magazine/july-2020/vote- or-postpone-electionsafrica-time-covid-19 (Accessed: 20 July 2020).

17. Dionne, Kim and Dulani, B. (2020) A Malawi court just ordered a do-over presidential election. Here's what you need to know, The Washington Post.

18. GLD-IPOR (2020) 'Malawians Don't Fear Covid-19 as much as Hunger, Loss of Access to healthcare and Stigma',The First GLD-IPOR COVID-19 Survey in Malawi. Available at: https://prezi.com/i/ffmbdzpiuou0/covidfears/.

19. International IDEA (2020) Global overview of COVID-19 impact on elections. Available at: https://www.idea.int/news-media/multimedia-reports/global-overview-covid-19-impact-elections.

20. Jain, V. and Yuan, J.-M. (2020) 'Systematic review and meta-analysis of predictive symptoms and comorbidities for severe COVID-19 infection', medRxiv. Cold Spring Harbor Laboratory Press. 
21. James, T. S. (2020) 'New development: Running elections during a pandemic', Public Money \& Management. Taylor \& Francis, pp. 1-4.

22. Kavanagh, M. M. and Singh, R. (2020) 'Democracy, Capacity, and Coercion in Pandemic ResponseCOVID 19 in Comparative Political Perspective', Journal of Health Politics, Policy and Law.

23. Landman, T. and Splendore, L. D. G. (2020) 'Pandemic democracy: elections and COVID-19', Journal of Risk Research. Taylor \& Francis, pp. 1-7.

24. Lappin, R. (2009) 'Why observe elections? Reassessing the importance of credible elections to postconflict peacebuilding', Peace Research. JSTOR, pp. 85-117.

25. Malawi Electoral Commission (2019) Announcement of the Determination of the Results of the Presidential Elections 2019. Blantyre.

26. Masina, L. (2020) 'Malawi Top Court upholds Presidential election re-run', Voice of America, 9 May. Available at: https://www.voanews.com/africa/malawi-top-court- upholds-presidential-election-rerun.

27. MCCI (2020) IMPACT OF CORONA VIRUS (COVID_19) ON BUSINESSES IN MALAWI. Lilongwe, Malawi.

28. Mohamed, A. (2020) 'How is the coronavirus pandemic affecting elections in Africa?', Aljazeera. Available at: https://www.aljazeera.com/news/2020/04/coronavirus- pandemic-affecting-electionsafrica-200409085324155.html.

29. O'Neill, S. et al. (2016) 'Estimating causal effects: considering three alternatives to difference-indifferences estimation', Health Services and Outcomes Research Methodology. Springer, 16(1-2), pp. $1-21$.

30. Public Health Institute of Malawi (2020) Malawi Covid-19 Daily situation report-3rd July. Todaro, S. C. and Smith, M. P. (2012) Economic development. 11th edn. New York: Addison-Wesley.

31. Tostensen, A. (2019) "The Tipp-Ex election": Widespread unrest after the 2019 elections in Malawi.

32. UNDP (2015) Sustainable development goals. New York: United Nations.

33. UNDP (2018) The sustainable development goals report. New York: United Nation. Available at: https://unstats.un.org/sdgs/report/2016/leaving-no-one-behind. UNICEF, WHO and +IFRC (2020) Key Messages and Actions for COVID-19 Prevention and Control in Schools.

34. World Health Organization, (WHO) (2020) Coronavirus (COVID-19). Available at: https://www.afro.who.int/health-topics/coronavirus-covid-19.

35. Yang, J. et al. (2020) 'Prevalence of comorbidities in the novel Wuhan coronavirus (COVID-19) infection: a systematic review and meta-analysis', International Journal of Infectious Diseases. Elsevier.

\section{Tables}

Table 1 - Variable Definitions 


\section{Variable Description}

\section{Dependent Variables}

Willingness to vote Binary variable $=1$ if a respondent indicated that they will definitely vote in the election; $=0$ otherwise

\section{Independent Variables}

Fear of COVID-19

If the respondent is afraid of catching COVID-19 $=1$ and 0 otherwise

Agrees with court to nullify election

Categorical variable $=1$ if agrees with the court's decision to nullify election; 0 , otherwise

Living conditions

1 =Very bad living conditions; 2=Fairy bad living conditions and $3=$ Good living conditions

Age

Binary; $18-24 ; 25-34 ; 35-44 ; 45-54 ; 55-64 ; 64+$

Male

Binary variable $=1$ if respondent is male; $=0$ if respondent is female

Employed

Binary variable $=1$ if respondent is employed; $=0$ if respondent is not employed

Jehovah's Witness

Binary variable $=1$ if respondent is Jehovah's witness; $=0$ if respondent is not Jehovah's witness

Education

Categorical variable $=0$ if No formal education; $1=$ Primary; $2=$ Secondary; 3 = Post-secondary

Urban

Binary variable $=1$ if respondent is based in urban area; $=0$ if respondent is based in rural area

Region of residence

Categorical variable, if respondent is based in: $1=$ North; $2=$ Centre; $3=$ South

Table 2 - Socio and demographic characteristics 


\begin{tabular}{|c|c|c|}
\hline Variables & $\%$ & $\underline{\mathrm{n}}$ \\
\hline Will definitely vote & 86 & 990 \\
\hline Perceived risk of catching COVID-19 & $63 \%$ & 728 \\
\hline Age 18-24 & $19 \%$ & 217 \\
\hline Age $25-34$ & $28 \%$ & 322 \\
\hline Age $35-44$ & $21 \%$ & 243 \\
\hline Age $45-54$ & $15 \%$ & 172 \\
\hline Age $55-64$ & $9 \%$ & 106 \\
\hline Age $>64$ & $8 \%$ & 95 \\
\hline Male & $53 \%$ & 608 \\
\hline No education & $9 \%$ & 105 \\
\hline Primary education & $55 \%$ & 639 \\
\hline Secondary education & $29 \%$ & 340 \\
\hline Tertiary & $6 \%$ & 72 \\
\hline Religion is Jehovah's Witnesses & $1 \%$ & 3 \\
\hline Respondent is employed & $92 \%$ & 1067 \\
\hline Agrees with court to nullify election & $82 \%$ & 945 \\
\hline Respondent lives in urban & $17 \%$ & 200 \\
\hline Very bad living conditions & $42 \%$ & 483 \\
\hline Fairy bad living conditions & $33 \%$ & 380 \\
\hline Good living conditions & $25 \%$ & 292 \\
\hline Central region & $44 \%$ & 502 \\
\hline Northern region & $14 \%$ & 166 \\
\hline Southern region & $\underline{42 \%}$ & $\underline{487}$ \\
\hline Observations & 1155 & \\
\hline
\end{tabular}

Table 3 - Differences in characteristics 


\begin{tabular}{|c|c|c|c|c|}
\hline & (A) & (B) & (C) & (D) \\
\hline & No risky (0) & Risky (1) & $(0-1)$ & \\
\hline Variables & Proportion & Proportion & $d$ & p \\
\hline Age 18-24 & 0.223 & 0.182 & 0.041 & $(0.239)$ \\
\hline Age $25-34$ & 0.325 & 0.271 & 0.054 & $(0.166)$ \\
\hline Age $35-44$ & 0.175 & 0.216 & -0.042 & $(0.199)$ \\
\hline Age $45-54$ & 0.151 & 0.149 & 0.002 & $(0.948)$ \\
\hline Age 55-64 & 0.066 & 0.096 & -0.030 & $(0.167)$ \\
\hline Age $>64$ & 0.060 & 0.086 & -0.026 & $(0.212)$ \\
\hline Male & 0.422 & 0.543 & $-0.121^{\star \star}$ & $(0.004)$ \\
\hline No education & 0.084 & 0.092 & -0.008 & $(0.744)$ \\
\hline Primary education & 0.572 & 0.550 & 0.022 & $(0.594)$ \\
\hline Secondary education & 0.289 & 0.294 & -0.005 & $(0.894)$ \\
\hline Tertiary & 0.054 & 0.064 & -0.009 & $(0.623)$ \\
\hline Religion is Jehovah's Witnesses & 0.006 & 0.003 & 0.003 & $(0.634)$ \\
\hline Respondent is employed & 0.849 & 0.936 & $-0.087 * \star$ & $(0.003)$ \\
\hline Agrees with court to nullify election & 0.693 & 0.839 & 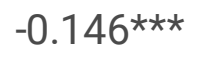 & $(0.000)$ \\
\hline Respondent stays in urban & 0.247 & 0.161 & $0.086^{*}$ & $(0.016)$ \\
\hline Very bad living conditions & 0.367 & 0.427 & -0.059 & $(0.147)$ \\
\hline Fairy bad living conditions & 0.422 & 0.313 & 0.108 ** & $(0.009)$ \\
\hline Good living conditions & 0.211 & 0.260 & -0.049 & $(0.159)$ \\
\hline Central region & 0.343 & 0.450 & $-0.107 * \star$ & $(0.009)$ \\
\hline Northern region & 0.060 & 0.158 & $-0.097 * \star \star$ & $(0.000)$ \\
\hline Southern region & 0.596 & 0.392 & $0.204^{\star \star \star}$ & $(0.000)$ \\
\hline$N$ & 166 & 989 & 1155 & \\
\hline
\end{tabular}

Table 4 - Effect of Covi-19 risk on voting 


\begin{tabular}{|c|c|c|c|}
\hline & OLS & Probit & IV 2SLS \\
\hline Variables & $\beta /$ ci95 & $\beta /$ ci95 & $\beta$ /ci95 \\
\hline \multirow[t]{2}{*}{ Perceived risk of catching COVID-19 } & -0.005 & -0.006 & $-0.096 * \star$ \\
\hline & {$[-0.047,0.036]$} & {$[-0.047,0.035]$} & {$[-0.175,-0.017]$} \\
\hline \multirow[t]{2}{*}{ Age $25-34$} & -0.007 & -0.005 & -0.008 \\
\hline & {$[-0.072,0.057]$} & {$[-0.061,0.051]$} & {$[-0.072,0.057]$} \\
\hline \multirow[t]{2}{*}{ Age $35-44$} & 0.042 & 0.047 & 0.043 \\
\hline & {$[-0.021,0.106]$} & {$[-0.014,0.108]$} & {$[-0.021,0.106]$} \\
\hline \multirow[t]{2}{*}{ Age $45-54$} & 0.010 & 0.010 & 0.012 \\
\hline & {$[-0.064,0.085]$} & {$[-0.059,0.079]$} & {$[-0.062,0.087]$} \\
\hline \multirow[t]{2}{*}{ Age $55-64$} & 0.045 & 0.054 & 0.042 \\
\hline & {$[-0.034,0.123]$} & {$[-0.030,0.138]$} & {$[-0.036,0.121]$} \\
\hline \multirow[t]{2}{*}{ Age $>64$} & 0.032 & 0.040 & 0.038 \\
\hline & {$[-0.050,0.114]$} & {$[-0.048,0.128]$} & {$[-0.046,0.122]$} \\
\hline \multirow[t]{2}{*}{ Male } & $0.042^{\star}$ & $0.043^{*}$ & $0.048 * *$ \\
\hline & {$[-0.003,0.087]$} & {$[-0.000,0.086]$} & {$[0.002,0.093]$} \\
\hline \multirow[t]{2}{*}{ Primary education } & -0.035 & -0.031 & -0.040 \\
\hline & {$[-0.108,0.038]$} & {$[-0.104,0.043]$} & {$[-0.113,0.033]$} \\
\hline \multirow[t]{2}{*}{ Secondary education } & -0.021 & -0.014 & -0.024 \\
\hline & {$[-0.103,0.062]$} & {$[-0.096,0.068]$} & {$[-0.107,0.058]$} \\
\hline \multirow[t]{2}{*}{ Tertiary } & -0.021 & -0.004 & -0.025 \\
\hline & {$[-0.127,0.085]$} & {$[-0.116,0.107]$} & {$[-0.133,0.083]$} \\
\hline \multirow[t]{2}{*}{ Religion is Jehovah's Witnesses } & -0.126 & -0.119 & -0.120 \\
\hline & {$[-0.561,0.309]$} & {$[-0.411,0.173]$} & {$[-0.545,0.305]$} \\
\hline \multirow[t]{2}{*}{ Respondent is employed } & $0.129 * \star \star$ & $0.098^{\star \star \star}$ & $0.138^{\star * \star}$ \\
\hline & {$[0.033,0.225]$} & {$[0.034,0.162]$} & {$[0.043,0.233]$} \\
\hline \multirow[t]{2}{*}{ Agrees with court to nullify election } & $0.085^{\star *}$ & $0.069 * * *$ & $0.082^{\star *}$ \\
\hline & {$[0.018,0.151]$} & {$[0.020,0.118]$} & {$[0.016,0.148]$} \\
\hline Respondent lives in urban & $-0.076 * \star$ & $-0.071 * \star \star$ & 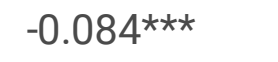 \\
\hline
\end{tabular}




\begin{tabular}{|llll|}
\hline Fairy bad living conditions & {$[-0.136,-0.016]$} & {$[-0.120,-0.022]$} & {$[-0.144,-0.023]$} \\
\hline Good living conditions & $-0.042^{\star}$ & $-0.045^{\star *}$ & $-0.050^{\star}$ \\
\hline & {$[-0.091,0.008]$} & {$[-0.089,-0.000]$} & {$[-0.099,0.000]$} \\
\hline Northern region & $0.047^{\star}$ & 0.041 & 0.041 \\
\hline & {$[-0.002,0.097]$} & {$[-0.011,0.094]$} & {$[-0.010,0.091]$} \\
\hline Southern region & $0.047^{\star}$ & $0.065^{\star}$ & 0.037 \\
\hline & {$[-0.000,0.094]$} & {$[-0.006,0.137]$} & {$[-0.011,0.085]$} \\
\hline N & $-0.071^{\star * \star}$ & $-0.067^{\star \star \star}$ & $-0.065^{\star \star}$ \\
\hline
\end{tabular}

${ }^{*} p<0.10, * \star p<0.05, * \star * p<0.01,95 \% \mathrm{Cl}$ in brackets 